\title{
Efficacy assessment of Pichia guilliermondii strain Z1, a new biocontrol agent, against citrus blue mould in Morocco under the influence of temperature and relative humidity
}

\author{
Rachid Lahlali ${ }^{\text {a,d,* }}$, Younes Hamadi ${ }^{\mathrm{b}, \mathrm{c}}$, M. El guilli ${ }^{\mathrm{c}}$, M. Haissam Jijakli ${ }^{\mathrm{a}, *}$ \\ a Plant Pathology Unit, Gembloux Agro-Bio Tech, University of Liege, Passage des Déportés, 2, 5030 Gembloux, Belgium \\ ${ }^{\mathrm{b}}$ Université Ibn Tofail, Faculté des sciences, Laboratoire de Phytopathologie, BP 133, 14000 Kenitra, Morocco \\ ' INRA-El Menzeh, Laboratoire de Phytopathologie, BP 293, 14000 Kenitra, Morocco \\ ${ }^{\mathrm{d}}$ AAFC-Saskatoon Research Centre, 107 Science Place, Saskatchewan, Canada S7N 0X2
}

\section{A R T I C L E I N F O}

\section{Article history:}

Received 17 February 2010

Accepted 3 December 2010

Available online $\mathrm{xxxx}$

\section{Keywords:}

Penicillium italicum

Pichia guilliermondii strain Z1

Temperature

Relative humidity

Postharvest

Biocontrol

\begin{abstract}
A B S T R A C T
The interactions of Penicillium italicum, which causes blue mould, and antagonistic yeast Pichia guilliermondii strain $\mathrm{Z1}$ were examined in controlled environments, to determine the influence of relative humidity (RH) $(45 \%, 75 \%, 85 \%, 98 \%$, and $100 \%)$ and temperature $(T)\left(5,10,15,20\right.$, and $\left.25^{\circ} \mathrm{C}\right)$. All main effects and interactions were significant $(P \leqslant 0.05)$, with the exception of interactions $\mathrm{RH} \times T$ and strain $\mathrm{Z1}(\mathrm{BCA}) \times \mathrm{RH} \times \mathrm{T}$. In the pathogen control, the lesion diameter of blue mould developed under all environmental conditions but was the largest at a RH range between $98 \%$ and $100 \%$, independent of the temperature. The efficacy of strain $\mathrm{Z} 1$ appeared to be independent of the environment and reduced disease incidence by more than $85 \%$ in all environmental conditions. Rapid colonization of the antagonistic yeast strain $\mathrm{Z} 1$ on citrus wounded sites was recorded during the first week at $5{ }^{\circ} \mathrm{C}$. Colonization then stabilized at $\pm 6.9 \times 10^{6} \mathrm{CFU} / \mathrm{ml}$ for 30 days. This indicates that $P$. guilliermondii is able to adapt itself and colonize the wound sites prior to the arrival of the pathogen, displaying greater efficiency than when colonizing wounds after pathogen. The antagonist was capable of growing in low concentrations of orange juice $(0.1-5 \%)$, with greatest growth at $5 \%$. Applying strain $\mathrm{Z1}\left(1 \times 10^{8} \mathrm{CFU} / \mathrm{ml}\right)$ as a formulated product significantly reduced the incidence of infected fruits and the percentage of infected wounds relative to the pathogen control. Disease control with formulated product (45\%) was slightly lower than that obtained with thiabendazole $(20 \%)$ or strain Z1 culturable cells (25\%). These results suggest that strain Z1 may be a useful BCA for control of blue mould under varying environmental conditions, and control may be enhanced by combining with other eco-friendly post-harvest treatments or improved formulation.
\end{abstract}

(c) 2010 Elsevier Inc. All rights reserved.

\section{Introduction}

Citrus fruits are an important fruit crop in the international trade, acquiring excellent quality and shelf life attributes, and are widely consumed both as fresh fruit or juice (FAO, 2004). Morocco is one of the largest exporter countries of citrus fruits, after Turkey, South Africa, USA and Spain (Citrus Commodity Notes, 2005).

Unfortunately, in developing countries, losses during transportation and storage of citrus fruits were estimated at over $50 \%$ of the harvested crop due to the lack of adequate protection measures (Eckert and Ogawa, 1985; Wisniewski and Wilson, 1992). Major postharvest losses due to their association with a variety of pathogens have been recorded on the export markets. Blue and green mould caused by Penicillium italicum Wehmer and Penicillium dig-

\footnotetext{
* Corresponding authors.

E-mail addresses: lahlali.r@gmail.com (R. Lahlali), MH.Jijakli@ulg.ac.be (M.H. Jijakli).
}

itatum Sacc., respectively, are the most common and serious diseases that affect citrus fruit quality in Mediterranean climates followed by sour rot caused by Geotrichum candidum Link ex Pers (Lahlali et al., 2004; Zhang et al., 2005; Caccioni et al., 1998; Homes and Eckert, 1999; Palou et al., 2002). It has been reported that the impact of these pathogens on the citrus industry differ from country to country. In Morocco, the losses have been estimated at over $60 \%$ and are generally controlled by applying chemical fungicides before or after harvesting (Taqarort et al., 2008). Imazalil, thiabendazole (TBZ) and sodium o-phenylphenol (SOPP) are the most commonly used synthetic chemical compounds in Morocco (Lahlali et al., 2004, 2005) and worldwide to control postharvest mould infections (Lahlali et al., 2009). Currently, there are no alternatives to these post-harvest chemicals in the citrus industry. Biological control of postharvest decaying of fruits and vegetables may provide an effective eco-friendly alternative to synthetic chemicals (Droby and Chalutez, 1999; Wilson et al., 1991; Lahlali et al., 2004). Compared to root or foliar diseases, biological control is a

1049-9644/\$ - see front matter (C) 2010 Elsevier Inc. All rights reserved. doi:10.1016/j.biocontrol.2010.12.001 
more suitable option for postharvest diseases, since the storage environment is relatively stable and fruits have a higher market value, which supports the higher cost of BCA's. Biocontrol may also provide a good tool to eliminate the problems caused by chemical residues in fruits as well as pathogen resistance development.

Several reports have underlined the use of microbial antagonists for controlling the postharvest citrus infections caused by Penicillium (Chalutz and Wilson, 1990; El-Ghouat et al., 2000; Lahlali et al., 2004, 2005;). Antagonistic microorganisms (fungal, yeast or bacteria) have been studied and evaluated for their potential in biocontrol programs (Lahlali et al., 2005; Janisiewicz and Korsten, 2002; Palou et al., 2008). To date, there are some commercial products available on the market such as SHEMER WDG (Metschnikowia fructicola; Agro Green, Israel), Bio-Save 10 LP (Pseudomonas syringae Strain ESC-10; JET Harvest Solutions, Orlando, FL, USA), Candifruit (Candida sake, Valencia, Spain), and Boniprotect ${ }^{\circledR}$ (Auerobasidium pullulans, Biofa AG, Germany). Other products are no longer available, such as Yieldplus (Cryptococcus albidus, Anchor, South Africa) for the control of pre-and post-harvest diseases of avocado, and Aspire ${ }^{\mathrm{TM}}$ (Candida oleophila, Ecogen, USA) for the control of postharvest diseases of apples, pears and citrus fruits (Vero et al., 2002). In Morocco, a few attempts have been made to develop safer, more eco-friendly methods for controlling postharvest fruit diseases. Using Belgian antagonistic yeast strains, Lahlali et al. $(2004,2005)$ reported the effectiveness of both strains Pichia anomala strain $\mathrm{K}$ and $\mathrm{C}$. oleophila strain $\mathrm{O}$ against green and blue moulds which was comparable to TBZ. Ameziane et al. (2007) evaluated the antifungal activity of Moroccan plants against post-harvest citrus fruit pathogens. They reported that, among 21 medicinal and aromatic plants tested, Thymus leptobotrys, Cistus villosus, and Peganum harmala plants completely suppressed the growth of $P$. italicum, $P$. digitatum and G. candidum in controlled conditions. Taqarort et al. (2008) screened three effective epiphytic yeast strains, P. anomala (YT73), Debaryomyces hansenii (YT22) and Hanseniaspora guilliermondii (YT13) against $P$. digitatum among a collection of 245 strains.

The objective of this work was to investigate the effectiveness of epiphytic yeast $P$. guilliermondii strain $\mathrm{Z1}$, isolated from the surface of healthy orange fruit, as an eventual biocontrol agent (BCA) of citrus blue mould. The efficacy of strain $\mathrm{Z} 1$ was tested under different temperatures and relative humidity regimes. We evaluated its population dynamics at 5 and $25^{\circ} \mathrm{C}$ as well as its survival in sterile distilled water (SDW) or at different concentrations of orange citrus juice. Finally, its efficacy as culturable cells (strain Z1 produced in Petri dishes) and as a formulated product was determined and compared to that of a conventional chemical (TBZ) at commercial label rates.

\section{Material and methods}

\subsection{Microorganism preparation}

P. italicum, strain PIRGBH, was originally isolated from decayed Valencia-late orange fruits from Elgharb Chrarda Beni Hssen in Morocco by the laboratory of Phytopathology of INRA-El Menzeh. For long term storage, the pathogen was maintained in $25 \%$ glycerol at $-80^{\circ} \mathrm{C}$. Before the experiment, it was recovered from the glycerol and grown on potato dextrose agar (PDA) medium (Merck, Darmsdt, Germany). The conidial suspensions were prepared from a \pm 7 day-old pathogen culture by recovering the surface of the colonies in $20 \mathrm{ml}$ of $0.05 \%$ Tween 20 . The content was filtered, homogenized and serially diluted in SDW to determine the cell count using Bürker's cell.

Pichia guilliermondii strain Z1 was isolated from healthy Moroccan Valencia-late oranges (Fig. 1A) and identified by Deutsche Sammlung von Mikroorganismen und Zellkulturen (DSMZ) (Germany). Stock cultures were stored at $4{ }^{\circ} \mathrm{C}$ on PDA plates. Before experiments, the start of the strain $\mathrm{Z} 1$ was subcultured at $25^{\circ} \mathrm{C}$ for three successive generations on PDA medium with an interval of $24 \mathrm{~h}$ and recovered in $0.85 \% \mathrm{NaCl}$ solution. The final concentration (CFU/ml) was determined as described above.

Biomass production of strain Z1 (Fig. 1B) was conducted at $28{ }^{\circ} \mathrm{C}$ in a 101 Biostat ${ }^{\circledR}$ ED Bioreactor (B. Braun Biotech. Germany). The culture medium used contains $50 \%$ glucose $(\mathrm{w} / \mathrm{w})$ as a carbon source, amino acids ( $30 \mathrm{~g}$ yeast extract and $30 \mathrm{~g}$ soy peptone), and either $5 \mathrm{ml}$ of mineral salts concentrated medium or $5 \mathrm{ml}$ of sterilized concentrated vitamin solution for growth. To increase the biomass production in relation to the batch system, feed-batch technology was used (Biotechnology Unit, Laboratory of Microbiology, ULB, Belgium). The biomass produced in the feed-batch was dried in a fluid bed dryer. Maize starch was used as a loading agent (30\%). Air temperature in the bed was maintained at $30^{\circ} \mathrm{C}$ and air inflow at $150 \mathrm{~m}^{3} / \mathrm{h}$ throughout the drying process.

\subsection{Fruit preparation}

Citrus fruits cv. 'Valencia-late' (Citrus sinensis [L] Osbeck) were harvested from commercial orchards in Elgharb Chrarda Beni Hssen, Morocco. These fruits were stored at $4{ }^{\circ} \mathrm{C}$ for a maximum of 7 days and only healthy fruits were selected for the experiments. The fruits were disinfected by being soaked in a solution of sodium hypochlorite (10\%) for $2 \mathrm{~min}$ and then rinsed twice in SDW. After drying for one hour, oranges were wounded at two equidistant points at the equatorial site. Each wound was $5 \mathrm{~mm}$ in diameter and $4 \mathrm{~mm}$ in depth.
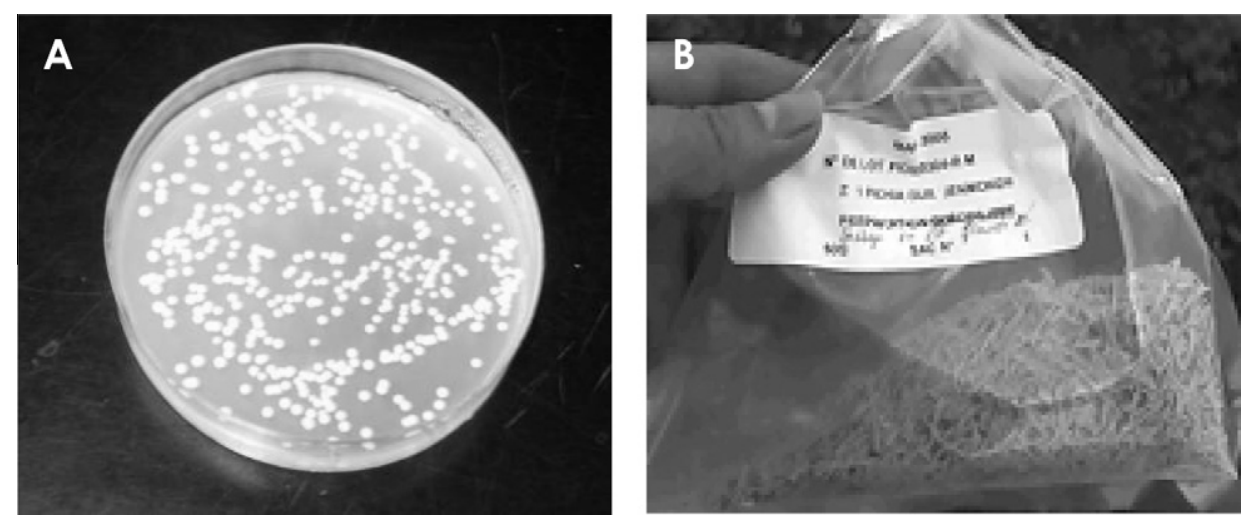

Fig. 1. P. guillermondii strain $\mathrm{Z} 1$ culturable cells (A) on PDA medium and as formulated strain $\mathrm{Z1}$ produced with feed-batch technology (B). 


\subsection{Effectiveness of strain $Z 1$ under different temperature and relative humidity regimes}

Fruits, prepared as previously described, were treated with $50 \mu \mathrm{l}$ of strain $\mathrm{Z} 1$ at a concentration of $1 \times 10^{8} \mathrm{CFU} / \mathrm{ml}$ and then inoculated $24 \mathrm{~h}$ later with $50 \mu \mathrm{l}$ of $P$. italicum at a concentration of $1 \times 10^{5}$ spores $/ \mathrm{ml}$. Fifty microliter of SDW was applied to the control before pathogen inoculation. To investigate the main effect of temperature $(T)$ and relative humidity $(\mathrm{RH})$ on the lesion diameter of $P$. italicum, fruits were kept in smaller desiccators with different relative humidities and then stored at each temperature treatment. This desiccator was a small growth chamber with a maximum capacity of 11 of water. With the exception of $100 \%$ $\mathrm{RH}$, in which the treated fruits were incubated in plastic bags containing moistened paper with water, the different approximate values of equilibrium relative humidity ( $98 \pm 1 \%, 85 \pm 1 \%, 75 \pm 1 \%$ and $45 \pm 1 \%$ ) inside the desiccators were controlled using the following saturated salt solutions with respect to studied $\mathrm{RH}: \mathrm{K}_{2} \mathrm{SO}_{4}$ (98\%), $\mathrm{KCL}(86.5 \%), \mathrm{NaCl}(75 \%)$ and $\mathrm{K}_{2} \mathrm{CO}_{3}(45 \pm 1 \%$ ) (Xu et al., 2001; Lahlali et al., 2008). Desiccators with different relative humidity regimes were incubated for $48 \mathrm{~h}$ at different experimental temperatures $\left(5,10,15,20\right.$ or $\left.25^{\circ} \mathrm{C}\right)$ before introducing the wounded oranges inoculated with strain $\mathrm{Z} 1$ and P. italicum. The relative humidity in each desiccator was checked daily by means of a thermo-hygrometer. There were three replicates per treatment, with each replicate consisting of four fruits (eight wounds) in a single desiccator. The experiment lasted 30 days for temperature tests ranging from 5 to $15^{\circ} \mathrm{C}$, and only 8 days for temperatures ranging from $20-25^{\circ} \mathrm{C}$. At the end of the experiment, the lesion diameters were recorded for the untreated and BCA-treated fruits at each temperature and $\mathrm{RH}$ combination.

\subsection{Population dynamics of strain Z1}

The cell survival of $P$. guilliermondii strain $\mathrm{Z1}$ was assessed on wounded 'Valencia-late' citrus fruits at 5 and $25^{\circ} \mathrm{C}$. Wounded fruits were inoculated with strain $\mathrm{Z} 1$ at $1 \times 10^{7} \mathrm{CFU} / \mathrm{ml}(50 \mu \mathrm{l}$ per wound) and then placed into moistened plastic boxes until use. There were three fruits (six wounds) per incubation time. The strain $\mathrm{Z} 1$ recovery from the wounded sites was made after 0 , $1,2,4,5$, and 10 days at $25^{\circ} \mathrm{C}$ and up to 30 days at $5^{\circ} \mathrm{C}$. The superficial tissues of the wounded sites were taken aseptically, with a sterile cork borer, and washed in a $50 \mathrm{ml}$ falcon tube containing $10 \mathrm{ml}$ of KPBT washing buffer $\left[\left(\mathrm{KH}_{2} \mathrm{PO}_{4} \quad(0.05 \mathrm{M}), \mathrm{K}_{2} \mathrm{HPO}_{4}\right.\right.$ $(0.05 \mathrm{M})$ and $0.05 \%$ of Tween $80, \mathrm{pH} 6.5)$ ] using Ultra-Thurrax T25 for 2 min. Tube contents were serially diluted 10 -fold in SDW and an aliquot of $100 \mu \mathrm{l}$ was plated in triplicate on PDA medium for each dilution, including stock. The plates were incubated at $25^{\circ} \mathrm{C}$ for $72 \mathrm{~h}$. This experiment was repeated twice and the results were evaluated as $\log \mathrm{CFU} /$ wound site versus incubation time for each temperature.

\subsection{Growth of strain Z1 in sterile distilled water}

A $50 \mathrm{ml}$ suspension of strain $\mathrm{Z1}$ at a concentration of $1 \times 10^{7} \mathrm{CFU} / \mathrm{ml}$ was prepared and incubated in a growth chamber, on a rotary shaker for 2 days. An aliquot of $1 \mathrm{ml}$ was taken and serially diluted 10-fold in SDW after incubation times of $0,1,2,3,4,24$, and $48 \mathrm{~h}$. One hundred microliter of each dilution was plated in four replicates on PDA medium. The Petri plates were incubated for $72 \mathrm{~h}$ at $25^{\circ} \mathrm{C}$. The experiment was repeated twice. The colony forming units ( $\mathrm{CFU} / \mathrm{ml}$ ) were counted and the result was expressed as the viability rate (\%) using the following formula:

Viability $(\%)=\frac{\text { Cell number }(\text { CFU }) \text { at time zero }}{\text { Cell number }(\text { CFU }) \text { at time }(t)} \times 100$

\subsection{Strain Z1 growth in different concentrations of orange juice}

Strain $\mathrm{Z} 1\left(1 \times 10^{7} \mathrm{CFU} / \mathrm{ml}\right)$ was prepared in a medium containing commercial orange juice at different concentrations $(0.1 \%, 0.5 \%$, $1 \%$ and $5 \%$ ). The $\mathrm{pH}$ of the medium was adjusted to 4.5 using concentrated $\mathrm{HCl}$ or $\mathrm{NaOH}$ and then shaken at $120 \mathrm{rpm}$ at $25^{\circ} \mathrm{C}$. After different incubation times, a $1 \mathrm{ml}$ suspension from each orange juice concentration was removed and serially diluted 10 -fold in SDW to reach a concentration of $1 \times 10^{3} \mathrm{CFU} / \mathrm{ml}$. An aliquot of $100 \mu$ l was spread on PDA medium in four replicates per dilution including stock culture. The Petri dishes were then incubated for $72 \mathrm{~h}$ at $25^{\circ} \mathrm{C}$ until they were ready for colony counting.

\subsection{Effectiveness of the formulated product of strain Z1 under controlled conditions}

Orange fruits were prepared as described above. Each wound was inoculated with $50 \mu \mathrm{l}$ of antagonistic yeast strain Z1 (fresh cells) at a concentration of $1 \times 10^{8} \mathrm{CFU} / \mathrm{ml}$, or strain $\mathrm{Z} 1$ formulated product $(1 \mathrm{~g} / 3 \mathrm{l}$ ) or chemical fungicide TBZ at $1000 \mathrm{ppm}$. Fruits that received a SDW treatment served as controls. Fruits were stored separately in moistened plastic boxes at ambient temperature for $24 \mathrm{~h}$ and then inoculated with $P$. italicum at $1 \times 10^{5}$ spores $/ \mathrm{ml}$ (50 $\mu \mathrm{l}$ per wound). Fruits were kept at $24^{\circ} \mathrm{C}$ for 7 days before disease evaluation. There were four replicates of 10 fruits (20 wounds) for each treatment and the result was expressed as the percentage of infected fruits and that of infected wounds in each treatment.

\subsection{Statistical analysis}

To assess the combined effect of temperature, relative humidity and strain $\mathrm{Z} 1$ on the lesion diameter of $P$. italicum on orange fruits, a full randomized factorial design was used. The main effect of temperature, relative humidity, and BCA and their interaction was analyzed using general linear model (GLM) procedure of SAS software (SAS Institute, version 8.2, Cary, NC, USA). A one way ANOVA was used to compare the effectiveness of strain Z1 culturable cells and the formulated product with that of the commercial fungicide TBZ. When analysis proved to be statistically significant, Duncan's multiple range test was employed for mean separation $(P \leqslant 0.05)$.

\section{Results}

\subsection{Effectiveness of strain $Z 1$ under different temperature and relative humidity regimes}

Variance analysis (ANOVA) showed a highly significant effect of strain $\mathrm{Z} 1$, temperature, and $\mathrm{RH}$, and both interactions strain $\mathrm{Z} 1 \times T$ and strain $\mathrm{Z} 1 \times \mathrm{RH}$, on the lesion diameter of $P$. italicum on Valencia

Table 1

Analysis of variance of the effect of temperature $(T)$, relative humidity (RH) and $P$. guilliermondii strain $\mathrm{Z} 1$ on lesion diameter of $P$. italicum.

\begin{tabular}{llrrrl}
\hline Source of variation & DF & \multicolumn{1}{l}{ SS } & \multicolumn{1}{l}{ MS } & \multicolumn{1}{l}{ F } & $P$-value \\
\hline Biocontrol agent (A) & 1 & 18716.48 & 18716.48 & 727.37 & $0.000^{*}$ \\
RH $(B)$ & 4 & 7250.44 & 1812.61 & 70.44 & $0.000^{*}$ \\
T $($ C $)$ & 4 & 1546.50 & 386.62 & 15.03 & $0.000^{*}$ \\
$\mathrm{~A} \times \mathrm{B}$ & 4 & 5378.62 & 1344.65 & 52.26 & $0.000^{*}$ \\
$\mathrm{~A} \times \mathrm{C}$ & 4 & 1176.61 & 294.15 & 11.43 & $0.000^{*}$ \\
$\mathrm{~B} \times \mathrm{C}$ & 16 & 481.22 & 30.08 & 1.17 & 0.299 \\
$\mathrm{~A} \times \mathrm{B} \times \mathrm{C}$ & 16 & 768.09 & 48.01 & 1.87 & 0.028 \\
Error & 150 & 3859.75 & & &
\end{tabular}

$\mathrm{DF}$, degree of freedom; SS, sum of squares; MS, mean square. Highly significant $(P \leqslant 0.05)$. 
late oranges (Table 1). Fig. 2 demonstrates that strain $\mathrm{Z} 1$ reduced the blue mould lesion diameter by $85 \%$ on wounded citrus fruits under different temperature and $\mathrm{RH}$ regimes compared to the pathogen control. The biocontrol activity seems to be independent of environmental factors. It appears that the P. italicum lesion diameter decreased with decreasing temperature and $\mathrm{RH}$ values, with the exception of temperatures 10 and $15^{\circ} \mathrm{C}$ where a lower growth difference was observed at a $\mathrm{RH}$ values ranging from $85 \%$ to $98 \%$. The lesion diameter was largest at a temperature of $25{ }^{\circ} \mathrm{C}$ and $100 \% \mathrm{RH}$ and the lowest at $45 \% \mathrm{RH}$ independently of temperature (Fig. 2).

\subsection{Strain $Z 1$ population dynamics}

The ability of strain $\mathrm{Z1}$ cells to survive and multiply on wounded orange sites was assessed at $25^{\circ} \mathrm{C}$ (Fig. 3a) and $5{ }^{\circ} \mathrm{C}$ (Fig. 3b) for 30 days. At $25^{\circ} \mathrm{C}$, the yeast population in the wounds remained stable during the first $24 \mathrm{~h}$ and then increased to reach a maximum of $3.4 \times 10^{7} \mathrm{CFU} / \mathrm{ml}$ after 5 days of incubation. At $5{ }^{\circ} \mathrm{C}$, the number of strain $\mathrm{Z1}$ cells from wound sites dropped after the first 2 days, then, after 7 days of incubation increased to reach maximum of $1.7 \times 10^{7} \mathrm{CFU} / \mathrm{ml}$. The strain $\mathrm{Z} 1$ cell numbers remained constant after 10 days of incubation with a concentration of at least $6.9 \times 10^{6} \mathrm{CFU} / \mathrm{ml}$.

\subsection{Growth of strain $Z 1$ in sterile distilled water}

Fig. 4 shows the effect of incubation time on the survival of strain Z1 cell numbers in SDW. During the first $3 \mathrm{~h}$, the strain Z1 cell numbers were constant $\left(1 \times 10^{7} \mathrm{CFU} / \mathrm{ml}\right)$ and were shown to be unaffected by the incubation time and then increased exponentially to reach the plateau phase of $261.5 \%$ of viability after $24 \mathrm{~h}$ of incubation time. Cell numbers were approximately three times the initial concentration.
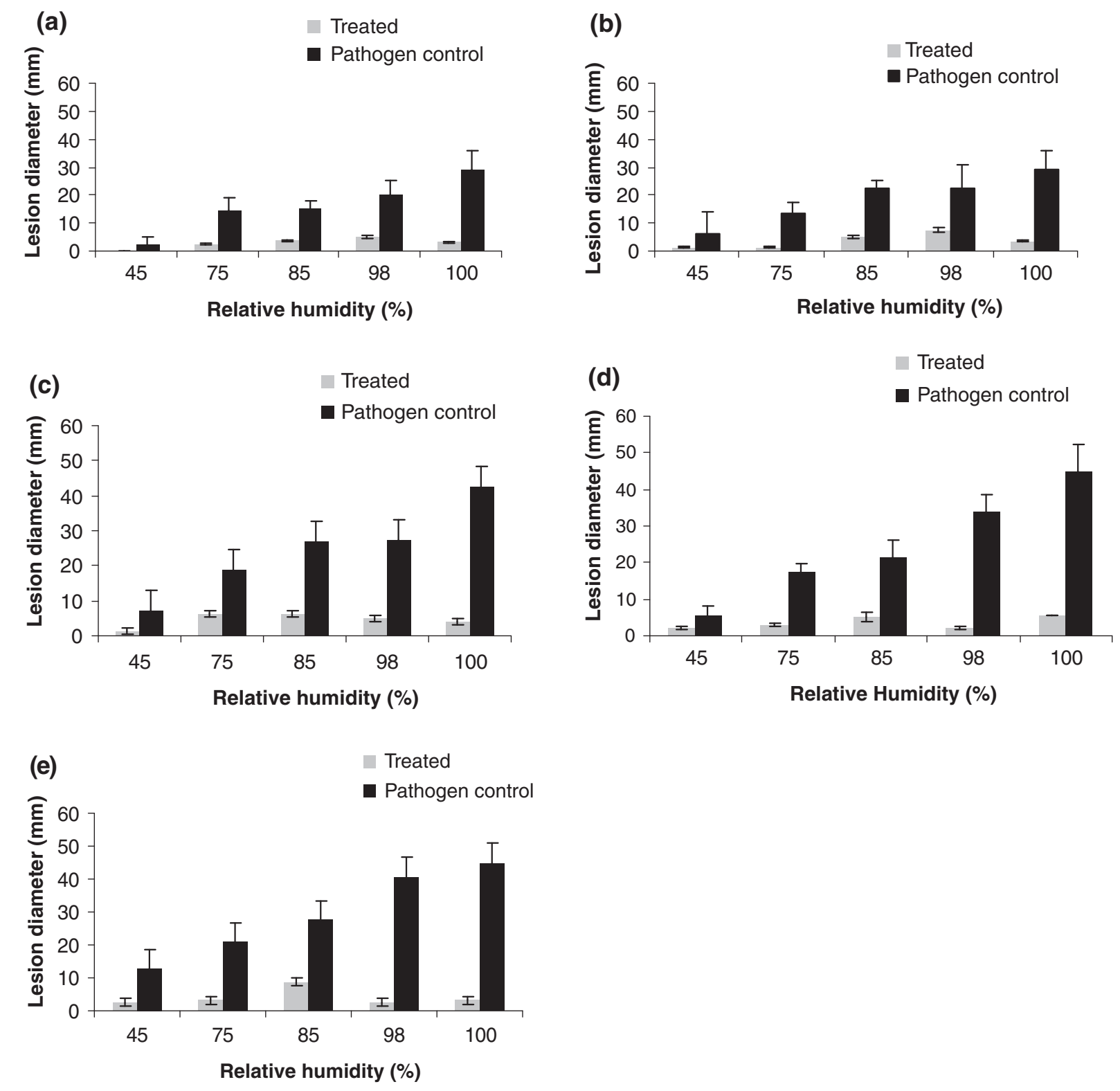

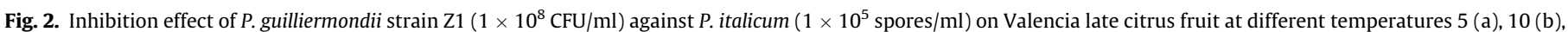

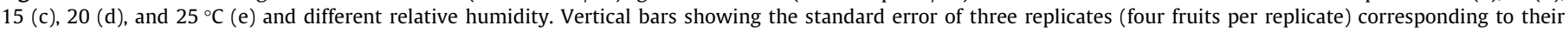
respective means. 
(a)
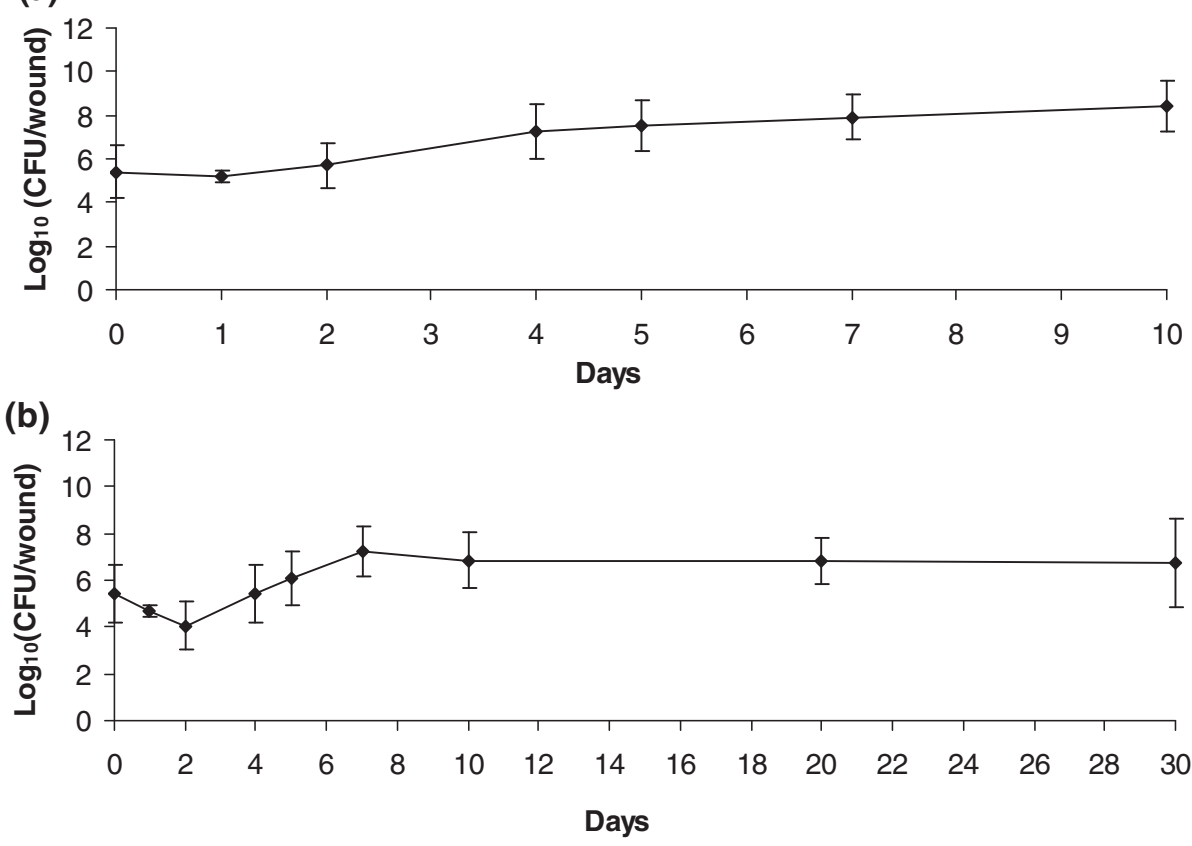

Fig. 3. P. guilliermondii strain $\mathrm{Z1}$ cell growth $\left(1 \times 10^{7} \mathrm{CFU} / \mathrm{ml}\right)$ at wounded citrus fruits $\left(50 \mu \mathrm{l}\right.$ per wound) was evaluated at 25 (a) and $5^{\circ} \mathrm{C}$ (b), respectively, for 10 and 30 days of incubation time. Vertical bars represent the standard error of two replicates corresponding to their respective means.

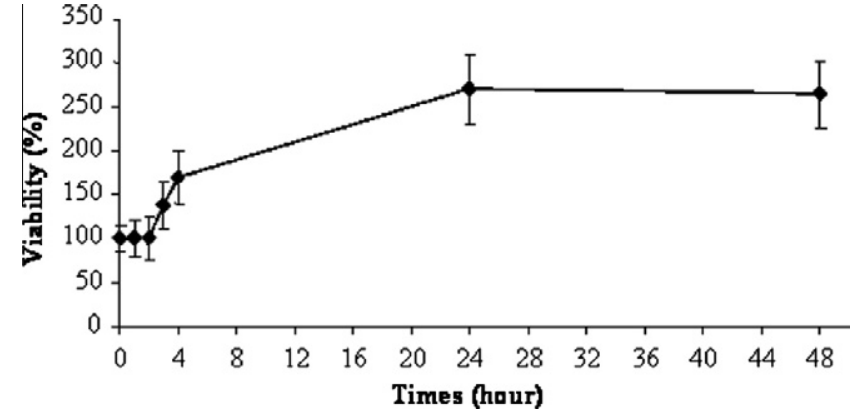

Fig. 4. Viability of $P$. guilliermondii strain $Z 1$ in SDW versus time of incubation (h). Vertical bars represent the standard error of two replicates corresponding to their respective means.

\subsection{Strain Z1 growth in different concentrations of orange juice}

The ability of strain $\mathrm{Z1}$ to survive and grow in orange juice was evaluated. A similar growth pattern was observed at different orange juice concentrations (Fig. 5). Cell numbers were similar for all concentrations for the first 6 days, and then differences were observed among the concentrations. For all concentrations, cell numbers increased to a maximum after 10 days, then slowly declined. In general, higher populations were observed with increasing orange juice concentration, with a maximum population of $2.9 \times 10^{12} \mathrm{CFU} / \mathrm{ml}$ at 10 days for $5 \%$ orange juice concentration. It appears there was no increase in strain Z1 cell numbers from 2 to 4 days (lag phase).

\subsection{Effectiveness of the formulated product of strain Z1 under controlled conditions}

The effectiveness of strain Z1, produced at an industrial scale, was evaluated against $P$. italicum and compared with strain $Z 1$ culturable cells and TBZ (1000 ppm) (Fig. 6). All applied treatments significantly reduced the incidence of decayed fruits caused by $P$. italicum relative to the untreated fruits (pathogen control). No significant difference in fruit disease incidence was observed between TBZ and strain Z1 culturable cells, while the percentage of infected fruit was slightly higher in the formulated strain $\mathrm{Z} 1$ product (Fig. 6a). The incidence of decayed fruits was reduced by $80 \%$, $75 \%$ and $55 \%$ in TBZ, strain Z1 culturable cells and formulated product respectively. Also, all treatments were significantly different from the untreated control (pathogen control) in terms of percentage of infected wounds. The percentage of infected wounds was significantly lower with chemical treatment, followed by strain Z1 culturable cells and formulated product with $10 \%, 22.5 \%$, and 42.5\%, respectively (Fig. 6b).

\section{Discussion}

Our work highlights a significant suppression of blue mould by $P$. guilliermondii strain $\mathrm{Z} 1$ on Valencia-late citrus fruits and supports this antagonistic yeast as a promising biocontrol agent of postharvest citrus fruits in Morocco and worldwide. This yeast species has been widely reported as an effective BCA against fungal pathogens, including blue and green mould of citrus fruits (Droby et al., 1993; Kinay and Yildiz, 2008), tomato spoilages (Saligkarias et al., 2002; Zhao et al., 2010) and Colletotrichum capsici on chilli fruit (Nantawanit et al., 2010). In all cases, the efficacy of an antagonistic yeast was dependent on the antagonist concentration and the pathogen inoculum concentration. Lahlali et al. (2004, 2005), Droby et al. (1989), and Nunes et al. (2001) reported that an increase of antagonist concentration resulted in greater effectiveness against post-harvest fungal pathogens at low pathogen pressure. Lahlali et al. (2004) underlined a highly significant variation of biocontrol efficacy with varying pathogen inoculum concentrations.

The strain Z1 demonstrated a consistent and significant efficacy against $P$. italicum under different temperature and RH combinations. This indicates that the antagonistic activity achieved by strain $\mathrm{Z1}$ was not significantly dependent on the environmental conditions as previously reported by Guetsky et al. (2001) against 


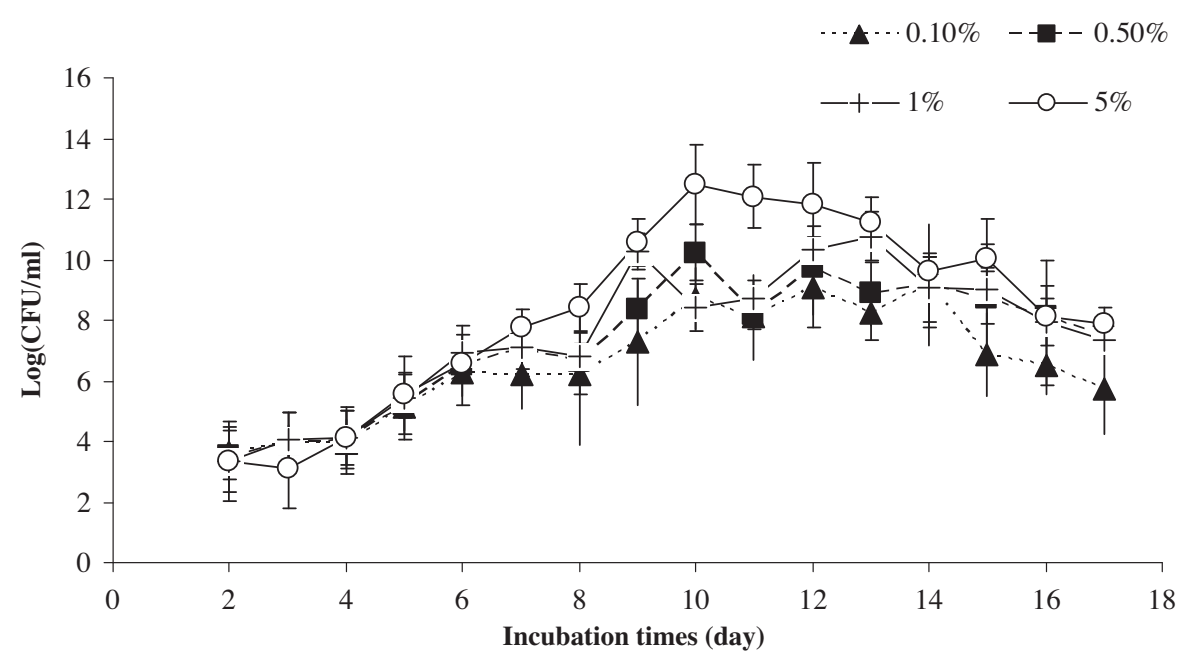

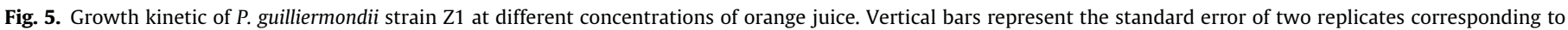
their respective means.

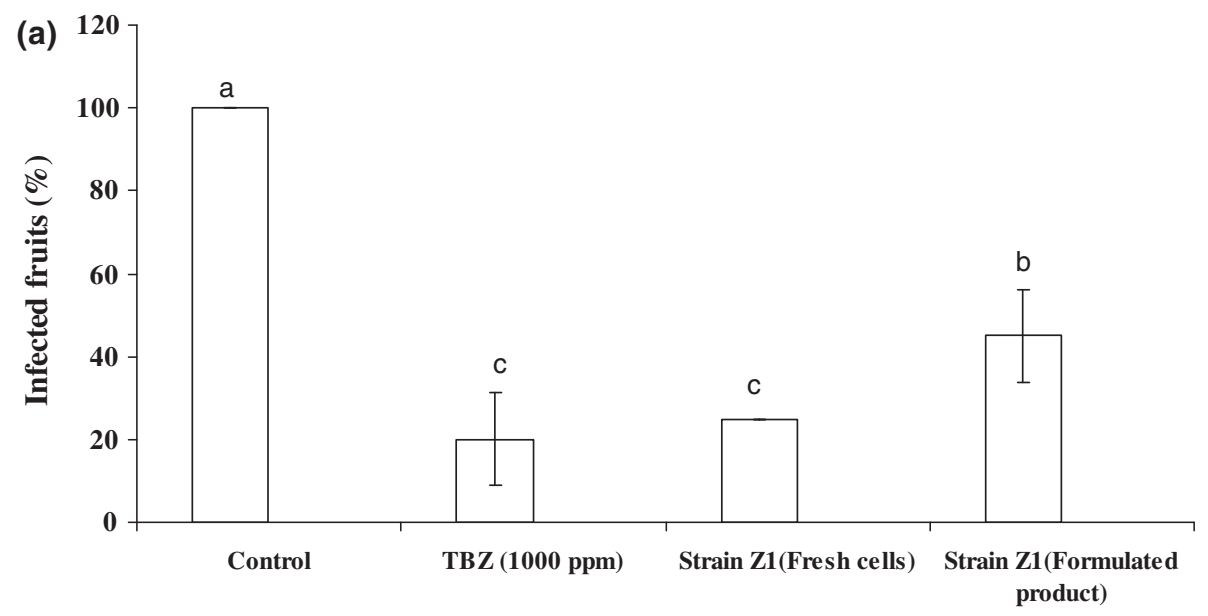

Treatment

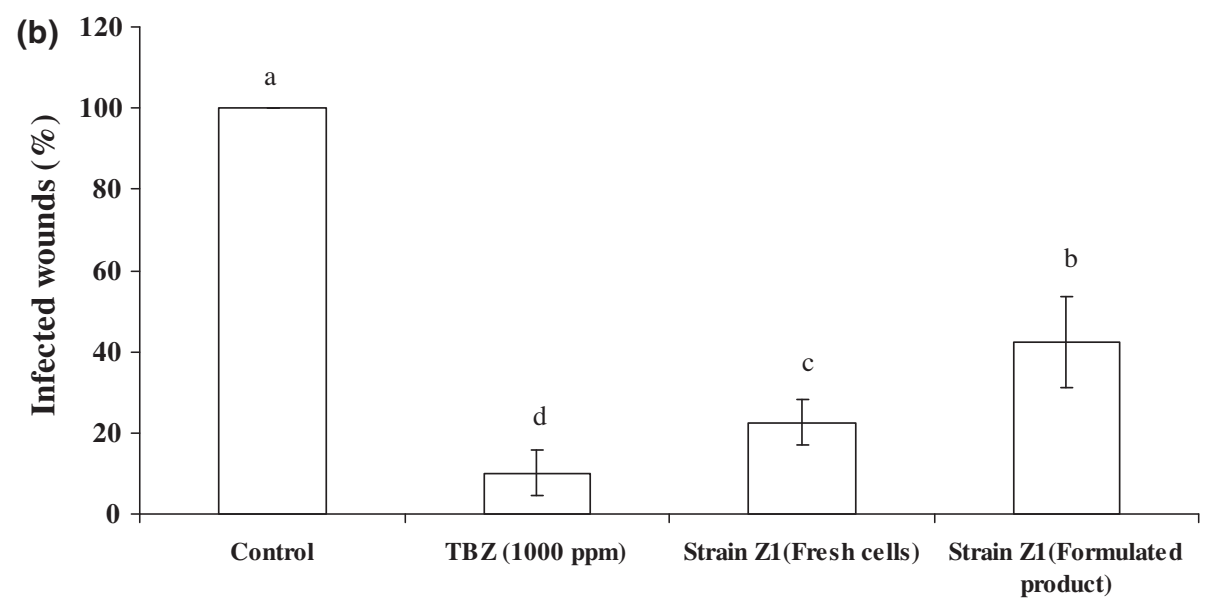

\section{Treatment}

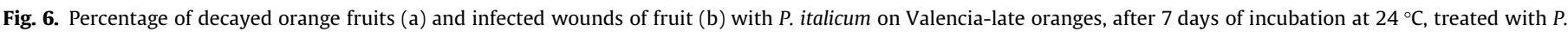

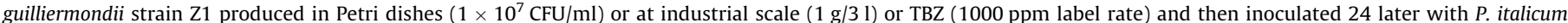

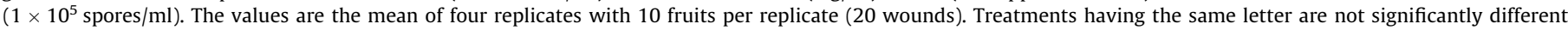
according to Duncan's multiple range test $(P \leqslant 0.05)$.

Please cite this article in press as: Lahlali, R., et al. Efficacy assessment of Pichia guilliermondii strain Z1, a new biocontrol agent, against citrus blue mould in Morocco under the influence of temperature and relative humidity. Biological Control (2010), doi:10.1016/j.biocontrol.2010.12.001 
Botrytis cinerea. This result could be attributed to the environment of the wound, which may protect the antagonist yeast against the adverse effects of environmental factors or by the time elapsing between the antagonist application and pathogenic inoculation. This result was unlike Lahlali et al. (2008) and Bonaterra et al. (2005), who reported a significant effect of environmental factors (temperature and relative humidity) when the BCA was applied directly on the fruit surface. However, with $P$. guilliermondii, the temperature and $\mathrm{RH}$ have proven to have a highly significant effect on the lesion diameter of $P$. italicum. The lesion diameter of $P$. italicum dropped with decreasing temperature and $\mathrm{RH}$ values with a maximum growth at $25{ }^{\circ} \mathrm{C}$ and $100 \% \mathrm{RH}$, and no growth detected at $35^{\circ} \mathrm{C}$ (data not shown) regardless of the RH value. This result is in concordance with those of Lahlali et al. (2006) and Plaza et al. (2003) and that reported on B. cinerea (Hannusch and Boland, 1996).

The study of strain $Z 1$ cell survival in wounded citrus fruits demonstrated a good adaptation of this BCA to cold storage temperatures. The yeast cell number at $5{ }^{\circ} \mathrm{C}$ was inferior to that observed at $25^{\circ} \mathrm{C}$. Furthermore, strain $\mathrm{Z1}$ was able to grow at the wounded sites which are the main entry points of postharvest citrus diseases. Fan and Tian (2001) showed a great difference in colonization of wounded apple fruits by antagonistic yeast Cryptococcus albidus at 23 and $1{ }^{\circ} \mathrm{C}$. Similar results were also obtained by others (Lahlali et al., 2005; Usall et al., 2001; Droby et al., 1989).

We also evaluated the survival of strain Z1 in SDW and at different concentrations of citrus orange juice. It was observed that the cell number remained around $1 \times 10^{7} \mathrm{CFU} / \mathrm{ml}$ during the first $3 \mathrm{~h}$ without being affected. Additionally, its growth followed the same pattern at different concentrations of citrus orange juice; however populations increased with increasing orange juice concentration. There was no increase in strain Z1 cell numbers from 2 to 4 days, suggesting that short periods of time is required for its adaptation to orange juice substrate. These results reinforce the ability of strain Z1 to survive and multiply in wounded sites and demonstrate that the compounds of these wounds did not constitute real limiting factors for its growth. Zhao et al. (2008) reported that $P$. guilliermondii was well-adapted to the environment of the tomato wound, competed for nutritional material and living space, and did not appear to secrete antibiotic. The authors concluded that the competition for nutrients and space seems to be the putative mode of action of this strain. Wisniewski et al. (1991) and Jijakli and Lepoivre (1998) reported a contradictory result by hypothesizing the involvement of cell wall degrading enzymes such as $\beta-1,3$-glucanase in the biocontrol activity of $P$. guilliermondii and $P$. anomala (strain $\mathrm{K}$ ).

The biocontrol experiment of formulated strain Z1 (industrial production) was assessed and compared with that of conventional fungicide TBZ (1000 ppm) and strain Z1 culturable cells. This step was of great importance for the large-scale application of this antagonistic yeast. Strain Z1 produced in Petri dishes gave a statistically similar result as that obtained with the chemical. However, the efficacy of the industrially produced strain $\mathrm{Z1}$ (formulated product) was significantly lower than that of TBZ and strain Z1 (Petri dish production). Similar results were obtained by Lahlali et al. (2005) for C. oleophila (strain O) and Obagwu and Korsten (2003) for Bacillus spp. To enhance biocontrol efficacy, several researchers have applied BCA in combination with other ecofriendly post-harvest methods. For example, applying $2 \%$ of $\mathrm{CaCl}_{2}$ together with Candida spp. or $P$. anomala (strain $\mathrm{K}$ ) improved the biocontrol efficiency of blue mould on apple fruits (Jijakli et al., 1998; McLaughlin et al., 1990; Wisniewski et al., 1995). Smilanick et al. (1999) demonstrated that using Pseudomonas syringae ESC-10 in a mixture with sodium carbonate (3\%) was more effective against green mould of citrus than treatments based only on Ca or the antagonist. Additionally, Yao et al. (2004) have found that the use of sodium bicarbonate (SBC) or hot water has significantly improved the efficiency of the antagonistic yeast against postharvest diseases of apples.

In summary, our results highlight a significant effect of strain $\mathrm{Z1}, \mathrm{RH}$ and temperature on the lesion diameter of $P$. italicum on oranges. The biocontrol efficiency obtained with antagonistic yeast strain $\mathrm{Z} 1$ seems unaffected by temperature and $\mathrm{RH}$ regimes. These results demonstrate the high potential of strain $\mathrm{Z} 1$ as a promising BCA for P. italicum on Valencia-late oranges over a wide range of temperature and $\mathrm{RH}$ combinations. Its effectiveness as a formulated product for the protection of wounded fruits was significantly lower compared to strain Z1 culturable cells or TBZ. However, prior to marketing, various studies should be planned from this work. First, the mode of action should be defined to boost the range of effectiveness, and to determine the mode and time of application to improve its formulation. Secondary, its effectiveness should be determined at large-scale before or after harvest.

\section{Acknowledgments}

The authors are grateful to DGCD-CUD (Direction Générale de la Coopération au Développement-Commission Universitaire pour le Développent) for its financial support in the case of PIC (Projet interuniversitaire ciblé) Morocco project. We thank Terry Tran (University of Manitoba, Canada) for English Editing.

\section{References}

Ameziane, N., Boubaker, H., Boudyach, H., Msanda, F., Jilal, A., Ait Benaoumar, A., 2007. Antifungal activity of Moroccan plants against citrus fruit pathogens. Agronomy for Sustainable Development 27, 273-277.

Bonaterra, A., Camps, J., Montesinos, E., 2005. Osmotically induced trehalose and glycine betaine accumulation improves tolerance to desiccation, survival and efficacy of the postharvest biocontrol agent Pantoea agglomerans EPS 125. FEMS Microbiology Letters 250, 1-8.

Caccioni, D.R.L., Guizzard, M., Biondi, D.M., Rena, A., Ruberto, G., 1998. Relationship between volatile components of citrus essential oils and antimicrobial action on Penicillium digitatum and Penicillium italicum. International Journal of Food Microbiology 43, 73-79.

Chalutz, E., Wilson, C.L., 1990. Postharvest biocontrol of green and blue mold and sour rot of citrus fruits by Debaryomyces hansenii. Plant Disease 74, 134-137.

Citrus Commodity Notes 2005. Developments in international citrus trade in 20042005.

Droby, S., Chalutez, E., 1999. Biological control of postharvest decay in citrus fruit. pp. 107-122. In: Marioschira (Ed.), Advances in postharvest diseases and disorders control of citrus fruit. Research Signpost, Trivandrum, India. European Journal of Plant Pathology 123, pp. 37-45.

Droby, S., Chalutz, E., Wilson, C.L., Wisniewski, M.E., 1989. Characterzation of the biocontrol activity of Debaryomyces hansenii in the control of penicillium digitatum on grapefruit. Canadian Journal of Microbiology 35, 794-800.

Droby, S., Hofstein, R., Wilson, C.L., Wisniewski, M., Fridlender, B., Cohen, L., Weiss, B., Daus, A., Timar, D., Chalutz, E., 1993. Pilot testing of Pichia guilliermondii: a biocontrol agent of postharvest diseases of citrus fruit. Biological Control 3, 4752 .

Eckert, J.W., Ogawa, J.M., 1985. The chemical control of postharvest diseases: subtropical and tropical fruits. Annual Review of Phytopathology 23, 421-454.

El-Ghouat, A., Smilanick, J.L., Wisniewski, M., Wilson, C.L., 2000. Improved control of apple and citrus fruit decay with a combination of candida saitoana and 2deoxy-D-glucose. Plant Disease 84, 249-253.

Fan, Q., Tian, S., 2001. Postharvest biological control of grey mold and blue mold on apple by Cryptococcus albidus (Saito) Skinner. Postharvest Biology and Technology 21, 341-350.

Food and Agricultural Organization (FAO) 2004. Citrus area harvest and production statistics.

Guetsky, R., Shtienberg, D., Elad, Y., Dinoor, A., 2001. Combining biocontrol agent to reduce the variability of biological control. Phytopathology 91, 621-627.

Hannusch, D.J., Boland, G.J., 1996. Interaction of air temperature, relative humidity and biological control agents on grey mold of bean. European Journal of Plant Pathology 102, 133-142.

Homes, G.J., Eckert, J.W., 1999. Sensitivity of Pencillium digitatum and P. Italicum to postharvest citrus fungicides in California. Phytopathology 89, 716-721.

Janisiewicz, Wj., Korsten, L., 2002. Biological control of postharvest diseases of fruits. Annual Review of Phytopathology 40, 411-441.

Jijakli, M.H., Lepoivre, P., 1998. Characterization of an exo-beta-1,3-glucanase produced by Pichia anomala strain K, antagonist of Botrytis cinerea on apples. Phytopathology 88, 335-343. 
Jijakli, M.H., Lepoivre, P., Grevesse, C., 1998. Yeast species for biocontrol of apple post-harvest diseases: an encouraging case of study for practical use. Biotechnological approaches in biocontrol of plant pathogens. Plenum Publishers, New York, USA. pp. 31-49.

Kinay, P., Yildiz, M., 2008. The shelf life and effectiveness of granular formulations of granular formulations of Metschnikowia pulcherrima and Pichia guilliermondii yeast isolates that control postharvest decay of citrus fruit. Biological Control $45,433-440$.

Lahlali, R., Massart, S., De Clercq, D., Serrhini, M.N., Creemers, P., Jijakli, M.H., 2009. Assessment of Pichia anomala (strain K) efficacy against blue mould of apples when applied pre- or post-harvest under laboratory conditions and in orchard trials. European Journal of Plant Pathology 123, 37-45.

Lahlali, R., Massart, S., Serrhini, M.N., Jijakli, M.H., 2008. A Box-Behnken design for predicting the combined effects of relative humidity and temperature on antagonistic yeast population density at the surface of apples. International Journal Food Microbiology 122, 100-108.

Lahlali, R., Serrhini, M.N., Friel, D., Jijakli, M.H., 2006. In vitro effects of water activity, temperature and solutes on the growth rate of $P$. Italicum Wehmer and $P$. digitatum Sacc. Journal of Applied Microbiology 101, 628-636.

Lahlali, R., Serrhini, M.N., Jijakli, M.H., 2004. Efficacy assessment of Candida oleophila (strain O) and Pichia anomala (strain K) against major postharvest diseases of citrus fruits in Morocco. Communications in Agricultural and Applied Biological Sciences 69, 601-609.

Lahlali, R., Serrhini, M.N., Jijakli, M.H., 2005. Development of a biological control method against postharvest diseases of citrus fruits. Communications in Agricultural and Applied Biological Sciences, Ghent University 70 (3), 47-58.

McLaughlin, R.J., Wisniewski, M.E., Wilson, C.L., Chalutz, E., 1990. Effects of inoculum concentration and salt solutions on biological control of postharvest diseases of apple with Candida sp. Phytopathology 80, 456-461.

Nantawanit, N., Chanchaichaovivat, A., Panijpan, B., Ruenwongsa, P., 2010. Induction of defense response against Colletotrichum capsici in chili fruit by the yeast Pichia guilliermondii strain R13. Biological Control 52, 145-152.

Nunes, C., Usall, J., Teixidó, N., Viñas, I., 2001. Biological control of postharvest pear disease using a bacterium Pantoea agglomerans (CPA-2). International Journal of Food Microbiology 70, 53-61.

Obagwu, J., Korsten, L., 2003. Integrated control of citrus green and blue moulds using Bacillus subtilis in combination with sodium bicarbonate or hot water. Postharvest Biology and Technology 28, 187-194.

Palou, L., Usall, J., Munoz, A., Smilanick, J.L., Vinas, I., 2002. Hot water, sodium carbonate, and sodium bicarbonate for the control of postharvest green and blue molds of Clementine mandarins. Postharvest biology and Technology 24, 93-96.

Palou, L., Smilanick, J.L., Droby, S., 2008. Alternatives to conventional fungicides for the control of citrus postharvest green and blue moulds. Stewart Postharvest Review 2, 1-16.
Plaza, P., Usall, J., Teeixido, N., Vinas, I., 2003. Effect of water activity and temperature on germination and growth of Penicillium digitatum, P. Italicum and Geotrichum candidum. Journal of Applied Microbiology 94, 549-554.

Saligkarias, D., Gravanis, F.T., Epton, H.A.S., 2002. Biological control of Botrytis cinerea on tomato plants by the use of epiphytic yeasts Candida guilliermondi strains 101 and US 7 and Candida oleophila strain I-182: I. in vivo studies I. Biological Control 25, 143-150.

Smilanick, J.L., Margosan, D.A., Milkota, F., Usall, J., Michael, I., 1999. Control of citrus green mold by carbonate and bicarbonate salts and influence of commercial roseum, a versatile adversary of Botrytis cinerea in crop. Plant Disease 81, 316328.

Taqarort, N., Echairi, A., Chaussod, R., et al., 2008. Screening and identification of epiphytic yeasts with potential for biological control of green mold of citrus fruits. World Journal of Microbiology and Biotechnology 24, 3031-3038.

Usall, J., Teixido, N., Torres, R., Eribe, X.O., Vinas, I., 2001. Pilot test of Candida sake (CPA-1) applications to control postharvest blue on apple fruit. Postharvest Biology Technology 21, 147-156.

Vero, S., Mondino, P., Burgaeno, J., Soubes, M., Wisniewski, M., 2002. Characterization of biological activity of two yeast strains from Uruguay against blue mold of apple. Postharvest Biology and Technology 26, 91-98.

Wilson, C.L., Wisniewski, M.E., Biles, C.L., McLaughlin, R., Chalutz, E., Droby, S., 1991 Biological control of postharvest diseases of fruits and vegetables: alternatives to synthetic fungicides. Crop Protection 10, 172-177.

Wisniewski, M., Biles, C., Droby, S., Mclaughlin, R.J., Wilson, C.L., Chalutz, E., 1991 Mode of action of the postharvest biocontrol yeast, Pichia guilliermondii. I. Characterization of attachment to Botrytis cinerea. Physiological and Molecular Plant Pathology 39, 245-258.

Wisniewski, M., Droby, S., Chalutz, E., Eilam, Y., 1995. Effects of $\mathrm{Ca}^{2+}$ and $\mathrm{Mg}^{2+}$ on Botrytis cinerea and Penicillium expansum in vitro and on the biocontrol activity of Candida oleophila. Plant Pathology 44, 1016-1024.

Wisniewski, M.E., Wilson, C.L., 1992. Biological control of postharvest diseases of fruits and vegetables: recent advances. HortScience 27, 94-98.

Xu, X.M., Guerin, L., Robinson, J.D., 2001. Effects of temperature and relative humidity on conidial germination and viability, colonization and sporulation of Monilia fructigena. Plant Pathology 50, 561-568.

Yao, H., Tian, S., Wang, Y., 2004. Sodium bicarbonate enhances biocontrol efficacy of yeasts on fungal spoilage of pears. International Journal of Food Microbiology 93, 297-304.

Zhang, H., Zheng, X., Xi, Y., 2005. Biological control of postharvest blue mold of oranges by Cryptococcus laurentii (Kufferath) Skinner. BioControl 50, 331-342.

Zhao, Y., Tu, K., Shao, X., Jing, W., Su, Z., 2008. Effects of the yeast Pichic guilliermondii against Rhizopus nigricans on tomato fruit. Postharvest Biology and Technology 49, 113-120.

Zhao, Y., Tu, K., Tu, S., Liu, M., Su, J., Hou, Y.P., 2010. A combination of heat treatment and Pichia guilliermondii prevents cherry tomato spoilage by fungi. International journal of Food Microbiology 137, 106-110 